\title{
Collaborative network organisations as platform for value co-creation in tourism destinations: an analysis of Foz do Iguaçu, Brazil
}

\author{
Adriana Fumi Chim-Miki* \\ Faculty of Tourism, Economics and Management, \\ University of Las Palmas de Gran Canaria, Campus Tafira, \\ 35010, Las Palmas de Gran Canaria, Spain \\ Email: adriana.chimmiki@gmail.com \\ *Corresponding author
}

\section{José Manoel Gândara}

Departament of Tourism,

Federal University of Paraná, Campus Reitoria, Dr. Faivre, 405 Street, Curitiba, PR, Brazil

Email: jmgandara@yahoo.com

\section{Rosa Maria Batista-Canino \\ Faculty of Tourism, Economics and Management, University of Las Palmas de Gran Canaria, Campus Tafira, 35010, Las Palmas de Gran Canaria, Spain \\ Email: rosa.batistacanino@ulpgc.es}

\begin{abstract}
This study investigated the co-creation of value in tourism by the collaborative network organisations (CNOs). The objective was to verify the degree of co-creation of value in the plans generated by participatory planning process in Foz de Iguaçu city, and to confirm that this process forms a platform to value co-creation in tourism destinations. The used methodology was a content analysis of a technical report and other documents related to the process of strategic-participatory assessment of Foz do Iguaçu city. This city is located at the three border zone between Brazil-Argentina-Paraguay, thus it is a shared tourism destination. The results indicated that the process of participatory planning, conducted by CNOs, can be a way to consumer-to-business-toconsumer (C2B2C) co-creation of value in tourism. Besides, the participatory planning is a tool of tourism governance, in which the $\mathrm{CNO}$ represents a hub between the relationships $\mathrm{B} 2 \mathrm{~B}, \mathrm{~B} 2 \mathrm{C}, \mathrm{C} 2 \mathrm{C}, \mathrm{C} 2 \mathrm{~B} 2 \mathrm{C}$, public-private sector and community, i.e., a platform with high capacity of value co-creation.
\end{abstract}

Keywords: tourism value co-creation; collaborative network organisations; CNOs; participatory planning; Foz do Iguaçu, Brazil; governance.

Reference to this paper should be made as follows: Chim-Miki, A.F., Gândara, J.M. and Batista-Canino, R.M. (2017) 'Collaborative network organisations as platform for value co-creation in tourism destinations: an analysis of Foz do Iguaçu, Brazil', Int. J. Tourism Policy, Vol. 7, No. 1, pp.42-57. 
Biographical notes: Adriana Fumi Chim-Miki received her $\mathrm{PhD}$ in Tourism, Economic and Management from University of Las Palmas de Gran Canaria, Spain, and received her MSc in Geography and Postgraduate in Environmental Management from Federal University of Rio Grande, Brazil. She is a Collaborator-Researcher in the University of Las Palmas de Gran Canaria, Spain. This research has the financial support of Capes Foundation, Ministry of Tourism, Brazil.

José Manoel Gândara received his $\mathrm{PhD}$ in Tourism and Sustainable Development from University of Las Palmas de Gran Canaria. He has a specialisation in International Marketing by the Italian Societa per L'Organizzazione Internazionale of Rome, specialisation in Tourism Economics from Bocconi University of Milan. He received his MSc in Tourism Management from Scuola Superiore del Commercio del Turismo i gave servizzi Milan. He is an Associate Professor in the Master in Tourism and $\mathrm{MD} / \mathrm{PhD}$ in Geography of the Federal University of Parana. Brazil.

Rosa Maria Batista-Canino received her PhD in Economic and Management Science from University of Las Palmas de Gran Canaria, Spain. She graduated from the Doctoral program in Entrepreneurship and Small Business Management at the Copenhaguen Business School (Denmark) and Växjö University (Sweeden). She is Professor Associate of the Doctoral program in Tourism, Economics and Management and Associate Professor in Entrepreneurship and Business in the Facultad de Economia, Empresa y Turismo of the Universidad de Las Palmas de Gran Canaria, Spain. She is a member of Instituto Universitario de Turismo y Desarrollo Económico Sostenible (TIDES).

This paper is a revised and expanded version of a paper entitled 'Governance as platform for value co-creation in tourism destinations: an analysis of Foz do Iguaçu, Brazil' presented at the 6th Advances in Tourism Marketing (ATMC) Conference, Joensuu, Finland, 8-10 September 2015.

\section{Introduction}

The tourism sector has the challenge to redesign products and restructure the strategic management to compete in the market. In face to this, the co-creation of value can provides a differentiator competitive (Prahalad and Ramaswamy, 2004a; Binkhorst, 2005, 2008). This redesign requires a great effort of coordination between all parts involved in the tourism sector, therefore to generate a network which creates value (Mariotti, 2002). The tourist perceives the destination as an integral product (Timón, 2004), thus the co-creation is more than the relationship between one company and its customers. In this case it is the sum of relationships between all destination stakeholders.

The shared management of a tourism destination can act positively on the value co-creation. This way, it acts as an aggregation factor for the co-creation of value. Nevertheless, the form in which the value is co-created within a set of relationships between destination stakeholders is an unexplored topic (Jaakkola and Hakanen, 2013). Although, this topic is noted as the 'new frontier' of knowledge on co-creation. The companies represent the linkages in community's collective platforms, being the new paradigm of value co-creation (Ramaswamy and Ozcan, 2014). 
Romero and Molina (2009, 2011) highlight the growing collaboration between organisations, which, alongside with customer communities generate emphasis on core competencies, personalisation and innovation of products, services and processes. A formal cooperative process between one or more organisations represents the collaborative network organisations (CNOs) that potentiates value co-creation (Camarinha-Matos and Afsarmanesh, 2006).

In the tourism sector, many times the $\mathrm{CNO}$ establishes a governance system for the destination. In other cases, they represent a strong network that contributes to tourism development, even if not reaching the complete status of governance. Thus, the CNO is a platform that can be used to promote the co-creation of value in the tourism sector. Mainly, in the American context, it is common that the convention visitors bureau (CVB) becomes the collective marketing vehicle and promotes the development of the whole destination. In this case, the CVB acts as a $\mathrm{CNO}$, since it promotes the integration between enterprises and other organisations, as well as, with the public administration (Wang, 2008).

This paper analyses if the process of participatory planning in the Foz do Iguaçu tourism destination generates co-creation of value. This destination is located in south Brazil in a three-border region between Brazil, Argentina and Paraguay. Note that this is one of the main tourism destinations in the three countries, where the famous Iguassu waterfalls are located.

This analysis was based primarily on technical work developed in 2011, entitled Ways of the Future: Developing the Destination We Want (Gândara et al., 2011). This technical work was the result of a participatory planning process performed by the tourism stakeholders. In sum, this paper aims to verify the degree of value co-creation on the plans generated by the tourism destination management through a participatory planning process. Thus, it confirms that this process can generate an interorganisational network that represents a platform of value co-creation. Secondly, we verify what kind of relationship between the tourism actors is source of value co-creation. The theoretical perspective of endogenous co-creation of value, focusing on the stakeholders' experiences is the principal base of these propositions (Ramaswamy and Ozcan, 2014).

\section{Theoretical foundation}

Traditionally, the value co-creation has been understood as a process involving interactions between the company and its customers. Indeed, it is a corporate process for the creation of goods, services and experiences in close cooperation with the experience and creativity of consumers (Romero and Molina, 2011; Ramaswamy and Ozcan, 2014).

The value co-creation has three principal theoretical perspectives. One of the foundations is the perspective of studies based on the service-dominant logic (S-D logic) (Vargo and Lusch, 2004, 2011). According to this logic, the client is an operant resource with different skills and knowledge that affects the way value is created when the service is consumed. As a result, the consumption relation always generates value co-creation (Prahalad and Ramaswamy, 2000, 2004a, 2004b).

On the other hand, some theoretical currents are based on the perspective of service logic (SD). Regarding this approach, the customer creates value when he combines resources provided by the company to other resources in his daily practice (Grönroos, 2008, 2011). However, only when interactions are established between the supplier and 
the customer, in a specific platform provided by the company, the value is co-created (Grönroos, 2006).

The third perspective is based on service science approach. This viewpoint considers that the co-creation of value occurs through the interaction between the resources available in a variety of service systems (Spohrer and Maglio, 2008). Therefore, this perspective has an approach focused in the value co-create in a macro level (Saarijärvi et al., 2013).

Traditionally, we have the notion of value co-creation between the company and its customer (B2C). However, recently Rihova et al. (2014) have conducted a research to verify the customer-to-customer $(\mathrm{C} 2 \mathrm{C})$ value co-creation in tourism. Their research is based on the literature perspective which conceptualises co-creation processes by customers in the notion of resource integration (Baron and Harris, 2008; McColl-Kennedy et al., 2012). According to this proposal (C2C), the customers interact with each other in physical or virtual areas, which are leisure contexts, sports, shopping, events, festivals, hospitality, and others. In this interaction, the customer uses the service and creates value through different social practices, such as strengthening family ties, the link with friends or helping strangers (Rihova et al., 2014).

In this same logic, but different contexts, the interaction between businesses (B2B) also generates value network platforms, as networks of complementary business or providers (Brandenburger and Nalebuff, 1996). However, the value co-creation also can occur in a network of competitors through a shared action between them. Prahalad and Ramaswamy (2004b) united these lines of reasoning in a proposal of value co-creation through a process of consumer-to-business-to-consumer (C2B2C). It is an economic activity model that challenges the traditional notions of creation of value. It is based on a joint effort between the company and its customer communities network in order to co-create value through their personalised experiences.

Figure $1 \mathrm{CNO}$ as a platform of tourism value co-creation

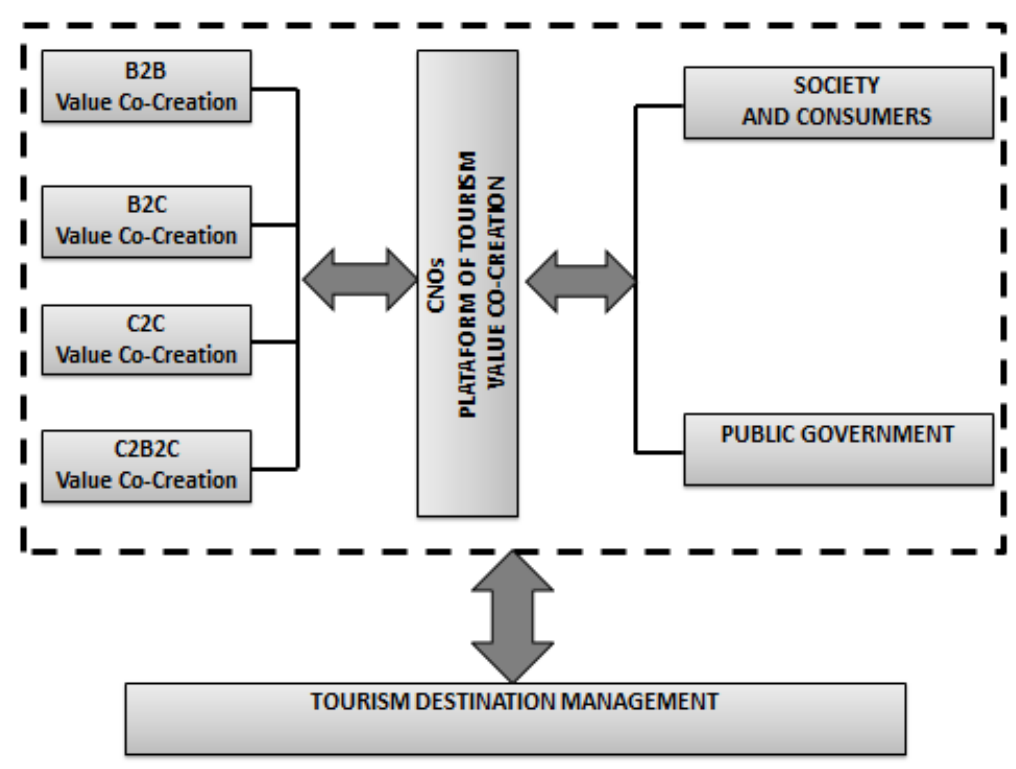

Source: Elaborated by the authors 
Likewise, when we apply this body of knowledge to the tourism sector, we can consider that all these networks and platforms coexist in a tourism destination (Figure 1). Therefore, the co-creation of value in tourism is a sum of these relationships $(\mathrm{B} 2 \mathrm{~B}+\mathrm{B} 2 \mathrm{C}$ $+\mathrm{C} 2 \mathrm{C}+\mathrm{C} 2 \mathrm{~B} 2 \mathrm{C})$ coordinated by an organisation.

The CNO (Camarinha-Matos and Afsarmanesh, 2006) articulates entrepreneurial, social and governmental organisations in order to develop the tourism destination in a holistic way. This set may or not reach a tourism governance status, but it promotes the co-creation of tourism value (Figure 1).

Binkhorst (2005) considers that the concept of co-creation is very adequate to be applied in tourism, because it adds value to both, visitors and visited, contributing to the destination's uniqueness. In this regard, note that a destination is a systemic relation between a multitude of components (Timón, 2004), where the territory becomes a part of the product through the tourism process that occurs inside it. The multitude of tourism experiences should be studied from multi-method, multi-disciplinary and multi-stakeholder approaches to generate tourism development towards an economic, social and environmentally sustainable model (Lugosi and Walls, 2013). In accordance to that, Saraniemi and Kylänen (2011) suggest to use the cultural approach to tourism destinations in order to go beyond the economic viewpoint. In doing so, they consider the poly-vocal issues of tourism, the complex relations between producers, consumers, local people, authorities and the co-creation of tourism experiences. So, they recommend joint forums and innovative interfaces where different actors can be interconnected (Saraniemi and Kylänen, 2011).

Furthermore, some features of tourism destinations generate a tendency to collaboration among the stakeholders, namely:

1 the vast majority of destinations have a scarcity of financial resources to develop an adequate marketing strategy and tourism development

2 the destinations are very vulnerable to sudden disasters and global risks, which impact on the set of organisations and society

3 the tourism industry has a great fragmentation of supplies with interdependence and complementarity among the firms (D’Angella and Go, 2009).

This is a suitable context to management based on cooperation, normally conducted by a destination organisation management (DMO). Many times, the DMO is a junction of public and private institutions, thus, it is a kind of CNOs.

Sometimes, this management system is legitimated by the stakeholders and evolves to the governance. In this sense, Mayntz (2000) considers governance as a new style of government, different from the hierarchical control model, characterised by a greater degree of cooperation and interaction between state and non-state actors embedded in a joint public-private network decision.

The analysis of management models to tourism destinations considering an integrated system has occupied a prominence place in the tourism academic studies. However, many of them use the governance perspective with conceptual and terminological ambiguities or inaccuracies (Queiróz and Rastrollo-Horrillo, 2015). In short, the term has been generalised to express management forms that there is public-private collaboration and joint action networks for the development of tourism destination. In the case analysed, the city of Foz do Iguaçú has created the 'Integrated Management', which is an institute to management the destination composed by different organisations, i.e., it is a CNO. 
Romero and Molina (2011) consider that in collaborative networks there is a high potential for value co-creation, giving the companies access to new knowledge, resources and shared risks, as well as, a complement to their skills/abilities and technologies. Additionally, the partnering induces the innovation, which is a source of value co-creation (Borys and Jemison, 1989).

The motives to the tourism sector implement Governance system (Velasco, 2008) or develop collaborative networks overlaps with two fundamental questions of value co-creation: 'why and how' (Ramaswamy and Gouillart, 2010) (Table 1). In fact, the co-creation of value is easier to apply in an enterprise, but in a destination context its use is still a gap. The destination management needs to develop a structure to create value in terms of integral destination.

Table 1 Motives to co-creation value and motives to apply the governance or CNO in tourism destination

\begin{tabular}{ll}
\hline $\begin{array}{l}\text { Why and how the stakeholders } \\
\text { can generate co-create value? }\end{array}$ & $\begin{array}{l}\text { Why the tourism sector is suited to governance system or } \\
\text { CNOs? }\end{array}$ \\
\hline $\begin{array}{l}\text { Stakeholders will not participate } \\
\text { with commitment in the } \\
\text { co-creation of value, unless it } \\
\text { produces value to them. }\end{array}$ & $\begin{array}{l}\text { The tourism developing needs collaboration between the } \\
\text { public-private sectors. Also, it needs involvement, in the } \\
\text { destination, of the host society, i.e., the involvement of } \\
\text { local population }\end{array}$ \\
$\begin{array}{l}\text { The best way to co-create value } \\
\text { is to focus on the experiences of } \\
\text { stakeholders. }\end{array}$ & $\begin{array}{l}\text { The tourism is eminently cross. For development it requires } \\
\text { the concurrence of various business sub-sectors } \\
\text { (accommodation, catering, transportation, brokerage ...) }\end{array}$ \\
$\begin{array}{l}\text { with separate logical and in many cases contradictory. } \\
\text { The stakeholders should be able } \\
\text { other. }\end{array}$ & $\begin{array}{l}\text { For the tourism stakeholders, the governance system is a } \\
\text { way to work usual, according to the logic of sector } \\
\text { organisation. The destination is the unifying action space } \\
\text { and the shared goal. }\end{array}$ \\
$\begin{array}{l}\text { The companies must provide } \\
\text { platforms that allow the } \\
\text { stakeholders interact and share } \\
\text { their experiences. }\end{array}$ & $\begin{array}{l}\text { Promotional platforms with public-private actors in tourism } \\
\text { destination already have shown great potential to develop } \\
\text { the sector. }\end{array}$ \\
\hline
\end{tabular}

Source: Elaborated by authors based on Ramaswamy and Gouillart (2010) and Velasco (2008)

Jaakkola and Hakanen (2013) suggest that the value creating increases when the participants are integrated and using resources jointly (Gummesson and Mele, 2010; Vargo and Lusch, 2011). Moreover, this value is determined on the basis of benefits and sacrifices perceived along the process or according to the results of this interaction (Ravald and Rönroos, 1996). The changes that tourism sector had suffered require a re-invention of the destination management in order to respond efficiently to the market (Fyall et al., 2012). The destination management organisation should be a hub, an orchestrator, thus the DMO depends on its ability to 'experience-centric' (D'Angella and Go, 2009). On the tourism context, it means that depends on its ability to sensitise stakeholders, making them aware about the high interdependence on the tourism sector. In this way, the stakeholders will create an interorganisational network, as well as, they can support a central coordination in the destination. Besides, the DMO depends on the ability to respond quickly, regarding to relationship B2B (stakeholders) and B2C (tourists). That is, directing them to a sustainable way, which can be assessed in terms of capability of both, DMO and stakeholders, engage in 'the art of collaboration' and 'the 
dynamic negotiation for value creation' (Prahalad and Ramaswamy, 2004b). At last, the DMO needs to be capable of developing values, culture and systems corporative (D'Angella and Go, 2009).

In a similar way, Fyall et al. (2012) identified three forms of collaboration through DMO structure: organic collaboration; mediated intra-destination collaboration and the mediated intra- and inter-destination collaboration. The first form (organic collaboration) occurs between specific components of an industry (for example between hotels), not being the best way to manage an integrally destination. In the second form (mediated intra-destination collaboration), the individual organisations are involved to cooperate due to market difficulties. In this case, the participants focus on creating value through collaboration in order to maintain its competitiveness. The third form (mediated intraand inter-destination collaboration) is generated when there is a context suitable to cooperation between destinations, such as a historical route, a gastronomic tourism area, or frequently between neighbouring destinations (Fyall et al., 2012).

Based on this theoretical background, this work establishes the relation between value co-creation and the participatory process for the development of a tourism destination promoted by a tourism destination management. This analysis contributes to theoretical development on value co-creation by interorganisational tourism network which is a still incipient area of knowledge.

\section{Methods and context of analysis}

This is an exploratory and qualitative analysis based on a documentary research. The analysis and validation of results was conducted through a pairing with previous studies and related theoretical frameworks. The use of pairing is justified when the objective is to find understanding about the phenomenon studied on a theoretical perspective, checking the association between theory and reality (Krippendorf, 1980).

We analysed final technical report of the participatory planning process in order to verify this process as a way to co-creation of value in tourism destination. Thus, firstly we performed a content analysis in this technical report. The set of prioritised and validated proposals by local stakeholders of tourism destination was analysed. Based on this analysis, we identify what proposals correspond to co-creation of value. Secondly, we analysed the path of participatory planning in order to confirm that was followed the process indicated in the theory of value co-creation by a group of stakeholders.

Foz do Iguaçu city has an inimitable tourism resource shared between Brazil-Argentina: the Iguaçu Falls. These immense waterfalls belong to the Iguaçu River, and are located 13 kilometres from the city centre (Brazil), 10 kilometres from Tancredo Neves Bridge (Argentina), 20 kilometres from the Friendship Bridge (Paraguay), and 30 kilometres from the Hydroelectric Power Plant Itaipu. The atmosphere generated by this natural resource creates a differentiated flora and fauna which can be observed in the Itaipu National Park (PNI). This park is listed by UNESCO as a World Natural Heritage (Domareski, 2011). In 2014, the city has occupied the 6th position on the ranking of tourism competitiveness in Brazil (MTur-Brazil, 2014). It received 2.57 million tourists in 2013 , which represents a high tourist density (9.8) for a city with 263,782 inhabitants (Paraná, 2014). 


\section{Research and results}

We identified that the participatory planning process conducted by the tourism government of Foz do Iguaçu destination was performed in two steps, as follow:

1 A phase of diagnostic process that includes a situational analysis performed by the stakeholders of the destination. This diagnostic was performed based on analysis of 19 documents related to tourism planning in the region, 15 in-depth interviews with local stakeholders and secondary data collected during the period 2006-2011. The documents analysed were reports, such as: municipal report of tourism planning, social balance report of Polo Iguassu (local institute created for tourism development), tourism inventory reports, annual reports of tourism local associations, annual report of Iguassu Convention Visitors and Bureau and, the statistical studies on tourism provided by the provincial government. In-depth interviews were applied in entrepreneurs and managers of tourism associations, so they participated in the process of planning the destination with ideas and suggestions.

2 A phase of proposition, validation and prioritisation of actions by the stakeholders. The validation of proposals was conducted through a strategic seminar with stakeholders. The result of this seminar has analysed by a focus group with 17 local experts in order to generate the final report of participatory planning. After eight meetings, the participants of focus group defined 20 proposals divided in three strategic areas: planning, management and control; marketing and innovation; quality and competitiveness.

In face of the exposed, the steps of participatory planning process performed by the tourism governance in Foz do Iguaçu destination can be considered similar to a co-creation process. In fact, there is a group of stakeholders that thinks and rethinks the tourism products, process, and management of the destination. The result of this process was new approaches and ideas to improve the destination. Besides, the form of conduct of this process allows interaction between stakeholders. This set of conditions is the way indicated by scholars of this topic to implement a process of co-creation of value.

On other hand, we analysed the result of the participatory planning, i.e., the proposals synthesised by the focus group and presented in the final report. In this sense, the present study analyses and classifies these proposals using as criteria the ability to co-create value according to the theoretical approach previously exposed. Thus, we highlighted the ability to add value from a customer-business-customer perspective (C2B2C), considering the knowledge of officers and tourism entrepreneurs, as well as, its experiences derived from direct contact with client as source of value co-creation.

The analysis demonstrated that this destination has an organisational level in terms of legitimised governance in the tourism sector. The stakeholders recognise the central coordination titled 'Integrated Management of Iguassu Destination'. The Iguassu Destination is considered by them as a tourism area around of the three border frontier, thus a shared destination between three countries. A total of 13 organisations participated in the planning process, represented by 17 people (Table 2). The participants established proposals to redirect the destination's strategy, in order to generate benefits and responsibilities to all involved. Of these proposals, 35\% are directly related to value co-creation; $20 \%$ are related indirectly; and $45 \%$ not related to this paradigm. 
Table 2 Participants in the process of tourism planning in Foz do Iguaçu city, Brazil

\begin{tabular}{|c|c|c|}
\hline $\begin{array}{l}\text { Organisation } \\
\text { acronym }\end{array}$ & Organisation & Number of participants \\
\hline SEBRAE & $\begin{array}{l}\text { Brazilian Support Service for } \\
\text { Micro and Small Business }\end{array}$ & SEBRAE business consultant (1) \\
\hline SINGTUR & Union of Paraná tour guides & President and a tourism guide (2) \\
\hline UDC & $\begin{array}{l}\text { Dynamics of the } \\
\text { Falls College Center }\end{array}$ & Coordinator of tourism program (1) \\
\hline SETU & Tourism State Office & Coordinator of regional office (1) \\
\hline SINDETUR & $\begin{array}{l}\text { Union of Paraná Tourism } \\
\text { Companies }\end{array}$ & President of the Union (1) \\
\hline ICVB & $\begin{array}{l}\text { Iguassu Convention and } \\
\text { Visitors Bureau (ICVB) }\end{array}$ & $\begin{array}{l}\text { President of ICVB; manager of Hotel } \\
\text { Continnental Inn; CEO of ICVB (3) }\end{array}$ \\
\hline SHRBS & $\begin{array}{l}\text { Union of Hotels, Restaurants, } \\
\text { Bars and Similar (SHRBS) }\end{array}$ & $\begin{array}{c}\text { President of SHRBS and manager of } \\
\text { Hotel Rafain Center (1) }\end{array}$ \\
\hline UNIOESTE & $\begin{array}{c}\text { State University of } \\
\text { West Paraná (UNIOESTE) }\end{array}$ & $\begin{array}{l}\text { Coordinator of hospitality } \\
\text { program of UNIOESTE (1) }\end{array}$ \\
\hline SENAC & $\begin{array}{l}\text { National Commercial } \\
\text { Training Service }\end{array}$ & Market relationship technician (1) \\
\hline ACIFI & $\begin{array}{l}\text { Commercial and Industrial } \\
\text { Association of Foz do Iguaçu } \\
\text { (ACIFI) }\end{array}$ & CEO of ACIFI (1) \\
\hline SMTU & Municipal Bureau of Tourism & $\begin{array}{l}\text { CEO of SMTU and director of } \\
\text { market relations (2) }\end{array}$ \\
\hline POLOIGUASSU & $\begin{array}{l}\text { International Institute } \\
\text { Polo Iguassu }\end{array}$ & President of POLOIGUASSU (1) \\
\hline ITAIPU & $\begin{array}{l}\text { Itaipu Binacional } \\
\text { Hydroelectric Plant }\end{array}$ & $\begin{array}{l}\text { Superintendent of social } \\
\text { communication of Itaipu (1) }\end{array}$ \\
\hline
\end{tabular}

Source: Ways of the Future: Developing the Destination We Want report (Gândara et al., 2011)

The result of this intervention has generated a total of eight proposals for the strategic area of planning, management and control; six proposals for the strategic area of marketing and innovation and six proposals for the strategic area of quality and competitiveness.

The first strategic area has eight proposals. Three of them directly related to generation of value co-creation (Figure 2). These proposals in the strategic area of 'planning, management and control' enable the co-creation of value in tourism, because they created a core of research, as a tourism observatory. Thus, it permits to know the consumer since its tourist experience, spreading this information among stakeholders. As a consequence, there is a processing of information resulting from $\mathrm{B} 2 \mathrm{~B}, \mathrm{~B} 2 \mathrm{C}$ and $\mathrm{C} 2 \mathrm{C}$ relations. In addition, the second proposal seeks to implement an information system to improve the relationship between the groups, that is, to generate shared knowledge and formalising a space of interaction which allows co-creation of value. Finally, the group defined as goal to rethink the role and structure of the DMO, a fact that by itself is co-creation of value for destination management. 
Co-creation scholars indicate the collective communities platforms as the new paradigm of value co-creation (Ramaswamy and Ozcan, 2014). Also, they consider the CNOs as sources of value co-creation (Camarinha-Matos and Afsarmanesh, 2006). According to this framework, the formation of core actors to study and share knowledge on supply, demand and impacts of tourism is a way to provide the co-creation of value. In same direction, the implementation of an information system in the tourism destination management produces inputs and feedbacks to the co-creation process. Also, based on the fundamental theory of co-creation, the extent that the group rethinks the role of tourism office the co-creation was generated (Prahalad and Ramaswamy, 2004b).

Figure 2 Proposals of strategic area of 'planning, management and control' and the tourism value co-creation

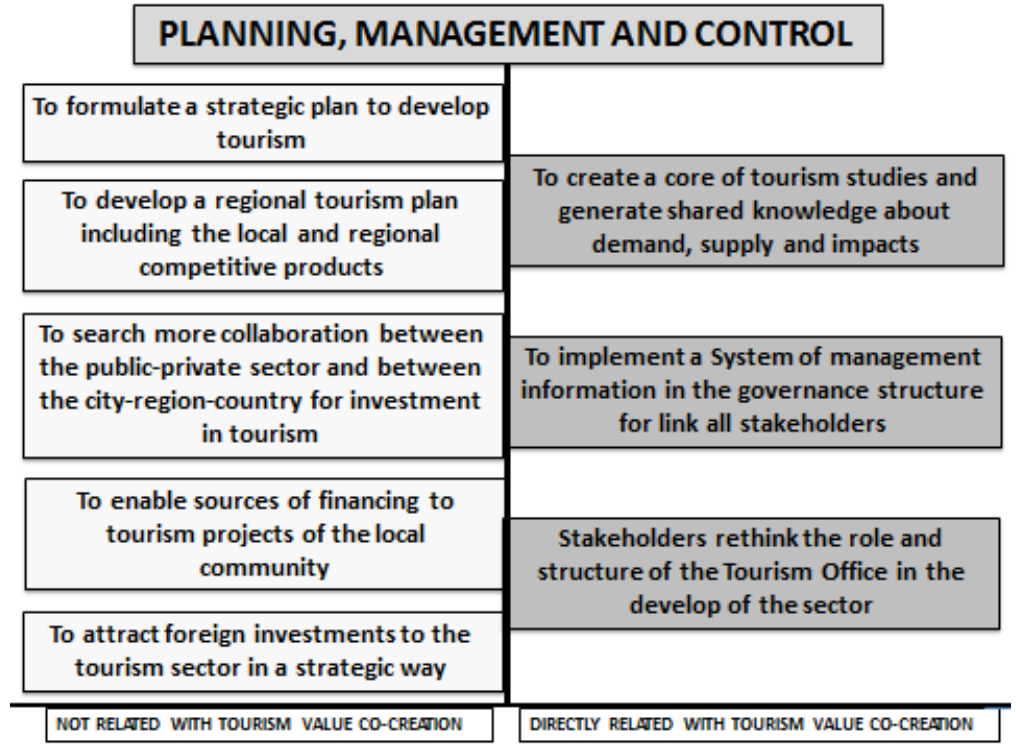

Source: Elaborated by the authors of Ways of the Future: Developing the Destination We Want report (Gândara et al., 2011)

The second strategic area resulted in six proposals, which two also contribute directly to value co-creation for the destination (Figure 3). The set of participants decided to perform a study on tourism consumer habits at the destination and to expand the use of ICT tools to generate direct interaction with customers. This is a way to generate value from the tourist's study in the context, that is, analysing the relationship $\mathrm{B} 2 \mathrm{C}$ and $\mathrm{C} 2 \mathrm{C}$. Also, they decided to install a virtual platform for the conclusion of the cycle of value creation, i.e., $\mathrm{C} 2 \mathrm{~B} 2 \mathrm{C}$.

The channel for suggestions and interaction among businesses and consumers is created, conducted under the integral management of destination. This proposal creates a tool that provides the most effective participation of consumers in the process of value co-creation, due to establishing a link on line with consumers. In the same sense, the demand studies provide a better understanding of consumer allowing add value to the products, services and processes of the tourism destination. All this procedures are part of the steps indicated by Prahalad and Ramaswamy (2004a) to an organisation implement and start a process of co-creation of value. 
Figure 3 Proposals for strategic area of 'marketing and innovation' and the tourism value co-creation

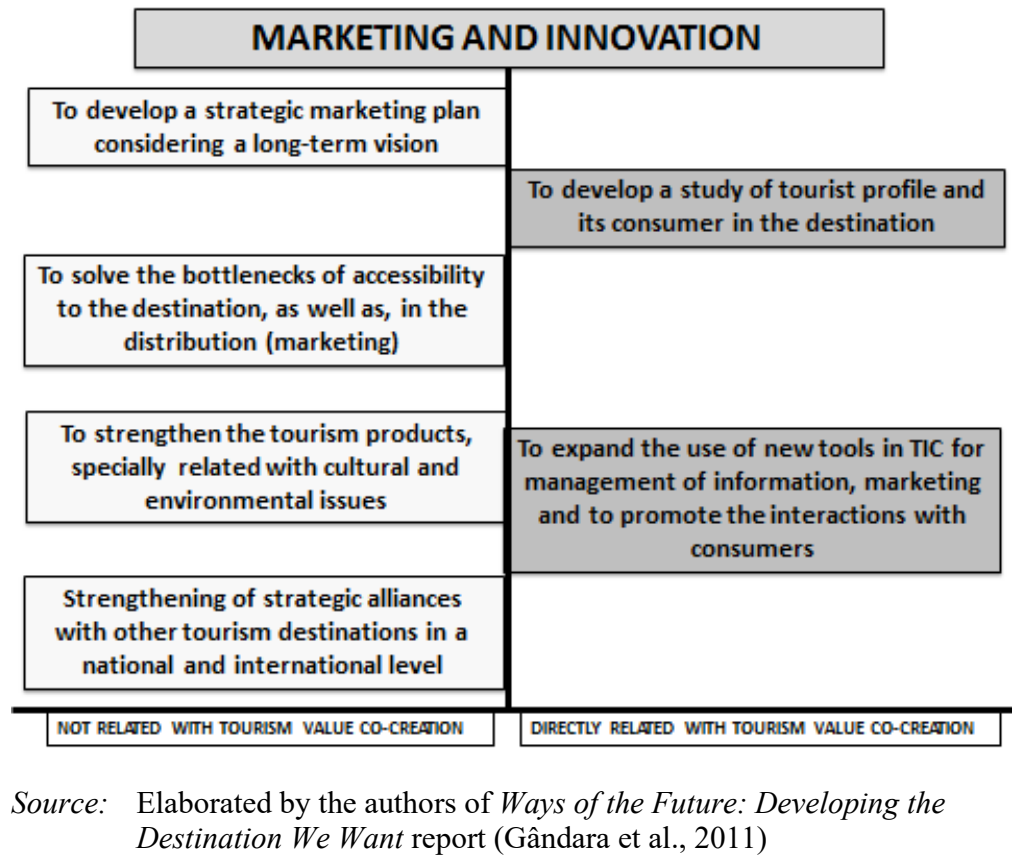

Finally, the third area presented six proposals related to a redesign of the destination. Thus, they need the information obtained from the proposals presented in the other two areas, specifically the information generated on proposals focused in co-creation of value. According to this viewpoint in the 'quality and competitiveness' area, four proposals were considered indirectly related, and other 2 were considered directly related with $\mathrm{C} 2 \mathrm{~B} 2 \mathrm{C}$ value co-creation in tourism (Figure 4). The proposals considered indirectly related to co-creation of value include the checking of deficiencies in the urban infrastructure, tourism equipment and human resources in order to establish and implement plans to improve them. Also focuses on improving the accessibility considering the particularity of Foz do Iguaçu city, which is located in a border region among three countries. All of these actions are dependent of studies and plans proposed in the other two strategic areas which were considered actions that led to co-creation of value.

Finally, the third area presented six proposals related to a redesign of the destination. Thus, they need the information obtained from the proposals presented in the other two areas, specifically the information generated on proposals focused in co-creation of value. According to this viewpoint in the 'quality and competitiveness' area, four proposals were considered indirectly related, and other 2 were considered directly related with C2B2C value co-creation in tourism (Figure 4). The proposals considered indirectly related to co-creation of value include the checking of deficiencies in the urban infrastructure, tourism equipment and human resources in order to establish and implement plans to improve them. Also focuses on improving the accessibility, considering the particularity of Foz do Iguaçu city, which is located in a border region among three countries. All of these actions are dependent of studies and plans proposed 
in the other two strategic areas which were considered actions that led to co-creation of value.

Figure 4 Proposals for strategic area of 'quality and competitiveness' and the tourism value co-creation

\begin{tabular}{|c|c|}
\hline \multicolumn{2}{|c|}{ QUALITY AND COMPETITIVENESS } \\
\hline \multirow{2}{*}{\begin{tabular}{|c|} 
To study the main problems in the \\
urban infrastructure and access, in \\
order to develop tourism and find ways \\
to implement improvements \\
\end{tabular}} & \\
\hline & \multirow{2}{*}{$\begin{array}{l}\text { To implement action of social and } \\
\text { environmental responsibility in the } \\
\text { tourism sector between all stakeholders } \\
\text { in order to become a global reference } \\
\text { destination }\end{array}$} \\
\hline \multirow{2}{*}{$\begin{array}{l}\text { To verify the needs of equipment and } \\
\text { tourist services and to make possible } \\
\text { the implementation of the projects in } \\
\text { this direction }\end{array}$} & \\
\hline & \\
\hline $\begin{array}{l}\text { To facilitate the mobility between the } \\
\text { city and region and, between the three } \\
\text { border countries }\end{array}$ & \multirow{2}{*}{$\begin{array}{l}\text { To qualify the most competitive tourism } \\
\text { products in order to comply with the } \\
\text { market's specific demands and to } \\
\text { improve the quality of the tourism } \\
\text { experience }\end{array}$} \\
\hline \multirow{2}{*}{$\begin{array}{l}\text { To qualify human resources to the } \\
\text { tourism sector considering the strategic } \\
\text { necessities }\end{array}$} & \\
\hline & \\
\hline INDIRECTLY RELATED WITH TOURISM VALUE CO-CREATION & DIRECTLY RELATED WITH TOURISM VALUE CO-CREATON \\
\hline
\end{tabular}

At last, two proposals were more directly related to the theory of value co-creation. The proposal to implement actions in order to develop awareness of social and environmental responsibility among stakeholders is creating shared value. And, the proposal to qualify the tourism product, aiming to generate a differentiated travel experience, is basically co-creating value to the tourism product offered by the destination.

The actions planned in this area are designing new products, processes and services with more added values to both tourist and destination. This design or redesign is based on collective effort of the participatory management members and the tourism destination management, so we considered as a process of value co-creation (Jaakkola and Hakanen, 2013; Ramaswamy and Ozcan, 2014). Definitely, it corresponds to the theoretical approaches of value co-creation.

\section{Discussions and conclusions}

This paper analyses the process of co-creation of value at Foz do Iguaçu by the groups organised at the Foz de Iguaçu destination. The elaboration of the participatory planning has transformed the $\mathrm{CNO}$ in a platform very suitable to this process. The paper presents the degree of value co-creation in the actions defined by the final report of participatory planning. Furthermore, the research verifies if participatory planning as a tool of integral management of the tourism destination follows a similar way to indicated to implement process of value co-creation. At the same time, the study confirmed which kind of 
relationship between the actors was the source of value co-creation. Thus, the analysis verifies how these tools and plans are become ways to co-create value as $\mathrm{C} 2 \mathrm{~B} 2 \mathrm{C}$ platforms for the tourism destination.

The CNOs are a hub between all relationships in the tourism sector, in other words, a hub between B2B, B2C, C2C, C2B2C, public-private sector and community. Indeed, we should be noted that the use of the CNOs as a nexus for the co-creation of value in tourism is also considered co-creating value in tourism management and not only in the tourism product, i.e., it is an innovation way in management, process, products and services.

The co-creation of value is a growing perspective in several industries. There is a recognised importance of this process for improve the competiveness of firms, as well as, to innovation of products and services. However, when the product is the tourism destination there are difficulties to establishing the co-creation process effectively. Thus, this research contributes to generate a theoretical approach in the direction of establishing a relationship between current practices of many destinations and the new theoretical perspective of value co-creation.

In Foz do Iguaçu city, the use of governance as a platform for value co-creation in the destination was not an intentional form, but an emerging way. The technical work was not developed based on value co-creation approach, but in the governance and strategic planning. The reformulation of the tourism product and suggestions received were based on the tourism experience, observed from the market and from informal interactions among companies and its customers at this destination. This means that the theoretical and empirical background was not focused on tools developed to promoting the value co-creation. However, seven proposals were directly related with the co-creation theory, representing $35 \%$ of the plan.

Ramaswamy and Ozcan (2014) indicate co-creation of value from the perspective of the actors' network, but should be with consumer participation. In the Foz do Iguaçu case, the consumer did not participate directly, however the network member's expertise, due to high experience in the sector, helped them to understand better the destination from the viewpoint of the consumer. On the other hand, the technical report noted that the governance system facilitates coordination, nevertheless requires better definition on the participants role have in a co-creation approach.

Anyway, the approach used in this destination is supported by the theory, which indicates that the value creation is not a linear function, but a co-evolutionary collaboration between allied stakeholders (C2B2C). This is indicated as a 'value constellation', however it is essential configure the role of the players (Normann and Ramirez, 1993; Ramaswamy and Ozcan, 2014).

These plans were developed in 2011, but, in the following years, we observed, through the national monitor, that the destination has improved its rankings of competitiveness (MTur-Brazil, 2014). Tourism governance at this destination shows a degree of advanced consolidation, with wide participation of the public, private and including participants of the three bordering countries. These facts are important because Foz do Iguacu city is one of the 'Mercociudades', a term given to cities belonging to the network created in 1995, covering municipalities in Mercosur which contribute to the exchange and cooperation among the economic bloc countries. Considering the Fyall et al. (2012) approaches, we can observe that the three ways of collaboration exist in the DMO structure of Foz do Iguaçu: organic collaboration, mediated intra-destination collaboration and the mediated intra- and inter-destination collaboration. 
We conclude that tourism destination management in Foz do Iguaçu city is propelling the value networking, contributing to innovation and the strategic positioning of the destination, so it acts as a facilitator to value co-creation. However, the competitiveness of this destination can grow even more if the local $\mathrm{CNO}$ becomes an intentional hub to $\mathrm{C} 2 \mathrm{~B} 2 \mathrm{C}$ co-creation of value in tourism.

Regarding to context analysed and under the perspective of co-creation of value we suggest two future recommendations. On the one hand, some practical actions are recommended to Foz do Iguaçu destination as facilitators to generation tourism co-creation in a more conscious way. On the other hand, further research is recommended to improve the theoretical background on the role of tourism governance or destination management by $\mathrm{CNO}$ in the co-creation of value. Thus, it is recommended that the destination management gather the participants of participatory tourism planning to implement an official platform of value co-creation. These stakeholders may be driven to co-create tourism value directed to the needs of the destinations based on topics presented by the central management during the year. It is also recommended that this platform for co-creation of value should be open to other participants, especially customers. In this sense, the co-creation of value emerges from a more integrated perspective of supply and consumption. The ideas generated by this platform of co-creation of value can be presented at meetings of participatory planning, in order to evaluate them and provide the plans to its execution. Therefore, both the $\mathrm{CNO}$ and participatory planning reach an evolutionary stage in management, since assumes the role of a true hub of the co-creation of value, conscious and guided, so, more effective.

The relation of governance perspective or CNOs as a way to implement process of co-creation in the tourism destination is unexplored topic, so further research on this theme is welcome. It is true that governance is a very specific management style, with a vast theoretical background; however, there are points of overlap with other theoretical perspectives. In case, we observe that the tourism governance uses participatory planning as one of its instruments. This process brings together actors to find solutions to shared problems and ideas for improving the tourism destination competitiveness, so generates co-creation of value. Within this framework, further studies on the overlap of these theoretical perspectives are recommended, aiming to develop tools to implementation of effective platforms of value co-creation in the tourism destinations.

\section{References}

Baron, S. and Harris, K. (2008) 'Consumers as resource integrators', Journal of Marketing Management, Vol. 24, Nos. 1-2, pp.113-130.

Binkhorst, E. (2005) The Co-Creation Tourism Experience, Whitepaper Co-creations, Sitges.

Binkhorst, E. (2008) 'Turismo de co-creación, valor añadido en escenarios turísticos', Journal of Tourism Research, Vol. 1, No. 2, pp.40-51.

Borys, B. and Jemison, D.B. (1989) 'Hybrid arrangements as strategic alliances', Academy of Management Review, Vol. 14, No. 2, pp.234-249.

Brandenburger, A.M. and Nalebuff, B.J. (1996) Co-Opetition, Harper Collins Business, Hammersmith, London, UK. 
Camarinha-Matos, L.M. and Afsarmanesh, H. (2006) 'Collaborative networks: value creation in a knowledge society’, in Wang, K., Kovacs, G.L., Wozny, M.J. and Fang, M. (Eds.): Knowledge Enterprise: Intelligent Strategies in Product Design, Manufacturing and Management, International Federation for Information Processing (IFIP), Vol. 207, pp.26-40, Springer, New York.

D'Angella, F. and Go, F.M. (2009) 'Tale of two cities' collaborative tourism marketing: towards a theory of destination stakeholder assessment', Tourism Management, Vol. 30, No. 3, pp.429-440.

Domareski, T.C. (2011) A Competitividade das Destinações Turísticas: O caso de Foz do Iguaçu $(P R), B R A S I L$, Master Thesis, Universidad del Vale do Itajaí, Balneario Camboriú.

Fyall, A., Garrod, B. and Wang, Y. (2012) 'Destination collaboration: a critical review of theoretical approaches to a multi-dimensional phenomenon', Journal of Destination Marketing and Management, Vol. 1, No. 1, pp.10-26.

Gândara, J.M.G., Biz, A., Chiquim, C.E. and Lago, H (2011) Caminhos do Turismo: Construindo o futuro do destino que queremos - Fase 2, SEBRAE, Foz do Iguaçu.

Grönroos, C. (2006) 'Adopting a service logic for marketing', Marketing Theory, Vol. 6, No. 3, pp.317-33.

Grönroos, C. (2008) 'Service logic revisited: who creates value? and who co-creates?', European Business Review, Vol. 20, No. 4, pp.298-314.

Grönroos, C. (2011) 'Value co-creation in service logic: a critical analysis', Marketing Theory, Vol. 11, No. 3, pp.279-301.

Gummesson, E. and Mele, C. (2010) 'Marketing as value co-creation through network interaction and resource integration', Journal of Business Market Management, Vol. 4, No. 4, pp.181-198.

Jaakkola, E. and Hakanen, T. (2013) 'Value co-creation in solution networks', Industrial Marketing Management, Vol. 42, No. 1, pp.47-58.

Krippendorf, J. (1980) Content Analysis: An Introduction to its Methodology, Sage Publications, London.

Lugosi, P. and Walls, A.R. (2013) 'Researching destination experiences: themes, perspectives and challenges', Journal of Destination Marketing and Management, Vol. 2, No. 2, pp.51-58, doi: 10.1016/j.jdmm.2013.07.001.

Mariotti, J.L. (2002) 'The value network', Executive Excellence, Vol. 19, No. 7, p.18.

Mayntz, R. (2000) 'Nuevos Desafíos de la Teoría de Governance', Instituciones y Desarrollo, Vol. 7, pp.35-51.

McColl-Kennedy, J.R., Vargo, S.L., Dagger, T.S., Sweeney, J.C. and van Kasteren, Y. (2012) 'Health care customer value cocreation practice styles', Journal of Service Research, Vol. 15, No. 4, pp.370-389.

MTur-Brazil - Ministry of Tourism (2014) Índice de competitividade do turismo nacional: destinos indutores do desenvolvimento turístico regional: relatório Brasil 2014, Brasília, DF.

Normann, R. and Ramirez, R. (1993) 'From value chain to value constellation: designing interactive strategy', Harvard Business Review, Vol. 71, No. 4, pp.65-77.

Paraná (2014) Estudo estatístico 20 anos de Turismo. Relatório PRTur e SEBRAE/PR, Curitiba, Paraná.

Prahalad, C.K. and Ramaswamy, V. (2000) 'Co-opting customer competence', Harvard Business Review, Vol. 78, No. 1, pp.79-87.

Prahalad, C.K. and Ramaswamy, V. (2004a) The Future of Competition: Co-Creating Unique Value with Customers, Harvard Business School Press, Boston, MA.

Prahalad, C.K. and Ramaswamy, V. (2004b) 'Co-creation experiences: the next practice in value creation', Journal of Interactive Marketing, Vol. 18, No. 3, pp.5-14.

Queiróz, F. and Rastrollo-Horrillo, M. (2015) 'El estado del arte en gobernanza de destinos turísticos', Tourism and Management Studies, Vol. 11, No. 2, pp.47-55. 
Ramaswamy, V. and Gouillart, F. (2010) 'Building the co-creative enterprise. Give all your stakeholders a bigger say, and they'll lead you to better insights, revenues', Harvard Business Review, Vol. 88, No. 10, pp.100-109.

Ramaswamy, V. and Ozcan, K. (2014) The Co-creation Paradigm, Stanford University Press, Stanford, California.

Ravald, A. and Rönroos, C. (1996) 'The value concept and relationship marketing', European Journal of Marketing, Vol. 30, No. 2, pp.19-30.

Rihova, I., Buhalis, D., Moital, M. and Gouthro, M.B. (2014) 'Conceptualising customer-tocustomer value co-creation in tourism', International Journal of Tourism Research, Vol. 17, No. 4, pp.356-363.

Romero, D. and Molina, A. (2009) 'Value co-creation and co-innovation: linking networked organizations and customer communities', in Camarinha-Matos, L.M., Paraskakis, I. and Afsarmanesh, H. (Eds.): Leveraging Knowledge for Innovation in Collaborative Networks, International Federation for Information Processing, AICT 307, Springer, New York, pp.401-412.

Romero, D. and Molina, A. (2011) 'Collaborative networked organizations and customer communities: value co-creation and co-innovation in the networking era', Production Planning and Control: The Management of Operations, Vol. 22, Nos. 5-6, pp.447-472, doi: 10.1080/09537287.2010.536619.

Saarijärvi, H., Kannan, P.K. and Kuusela, H. (2013) 'Value co-creation: theoretical approaches and practical implications', European Business Review, Vol. 25, No. 1, pp.6-19.

Saraniemi, S. and Kylänen, M. (2011) 'Problematizing the concept of tourism destination: an analysis of different theoretical approaches', Journal of Travel Research, Vol. 50, No. 2, pp.133-143.

Spohrer, J. and Maglio, P.P. (2008) 'The emergence of service science: toward systematic service innovations to accelerate co-creation of value', Production and Operations Management, Vol. 17, No. 3, pp.238-246.

Timón, D.A.B. (2004) 'El Concepto de Destino Turístico. Una aproximación geográfico-cultural', Estudios Turísticos, Vol. 160 (2004), pp.45-68.

Vargo, S.L. and Lusch, R.F. (2004) 'Evolving to a new dominant logic for marketing', Journal of Marketing, Vol. 68, No. 1, pp.1-17.

Vargo, S.L. and Lusch, R.F. (2011) 'Service-dominant logic: a necessary step', European Journal of Marketing, Vol. 45, Nos. 7/8, pp.1298-309.

Velasco, M. (2008) Gestión de destinos: ¿Gobernabilidad del turismo o gobernanza del destino? [online] http://www.esade.edu/cedit/pdfs/papers/pdf5.pdf (accessed 7 October 2013).

Wang, Y. (2008) 'Collaborative destination marketing: roles and strategies of convention and visitors bureaus’, Journal of Vacation Marketing, Vol. 14, No. 3, pp.191-209. 